ఠ

\title{
Prolongation of injection interval after switching therapy from ranibizumab to aflibercept in Japanese patients with macular edema secondary to branch retinal vein occlusion [Corrigendum]
}

Tagami M, Sai R, Fukuda M, Azumi A. Clin Ophthalmol. 2017;11:403-408.

Page 405, Comparison of injection intervals section, line 6, "We also compared the intervals between the last and the second-to the-last intravitreal injection of ranibizumab and the first and the second intravitreal injection of aflibercept" should have read "We also compared the interval between the last injection of ranibizumab and the first injection of aflibercept with the interval between the first and the second injection of aflibercept".
Clinical Ophthalmology

\section{Publish your work in this journal}

Clinical Ophthalmology is an international, peer-reviewed journal covering all subspecialties within ophthalmology. Key topics include: Optometry; Visual science; Pharmacology and drug therapy in eye diseases; Basic Sciences; Primary and Secondary eye care; Patient Safety and Quality of Care Improvements. This journal is indexed on

\section{Dovepress}

PubMed Central and CAS, and is the official journal of The Society of Clinical Ophthalmology (SCO). The manuscript management system is completely online and includes a very quick and fair peer-review system, which is all easy to use. Visit http://www.dovepress.com/ testimonials.php to read real quotes from published authors. 